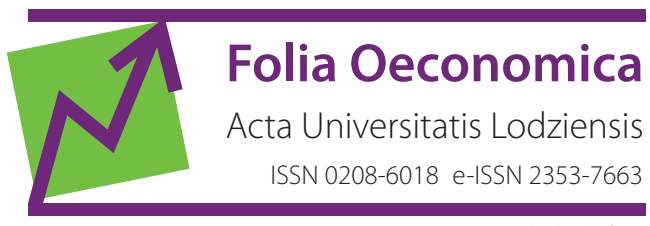

www.czasopisma.uni.lodz.pl/foe/

3(342) 2019

DOI: http://dx.doi.org/10.18778/0208-6018.342.07

\title{
Elżbieta Szulc
}

Nicolaus Copernicus University in Toruń, Faculty of Economic Sciences and Management

Department of Econometrics and Statistics, eszulc@umk.pl

\section{Dagna Wleklińska}

Nicolaus Copernicus University in Toruń, Faculty of Economic Sciences and Management

Department of Econometrics and Statistics, dagna.wleklinska@interia.eu

\section{Spatio-Temporal Analysis of the Impact of Credit Rating Agency Announcements on the Government Bond Yield in the World in the Period of 2008-2017}

\begin{abstract}
The paper concerns the impact of announcements published by rating agencies on the government bond yield in selected countries of the world. Ratings assigned to debt securities on account of the issuer's financial standing are an important determinant of their yield. Factors that affect the rate of return of a given traded debt, in addition to idiosyncratic factors, i.e. those related to the issuer's economy, and global factors, also include the ratings of connected countries. Moreover, empirical studies carried out in this area prove that the relationship is asymmetrical. This allows us to suppose that favourable information concerning the improvement of government bond ratings is not reflected in the decrease in their yield. The aim of the paper is the analysis of interactions between the yields of 10-year government bonds issued by selected economies. A subject that is of particular interest is the evaluation of the impact of positive and negative changes in credit rating assessments made by international agencies on the yield of bonds issued by other economies than the country concerned in the assessment. The spatial scope of the analysis concerns 10-year government bonds issued by 40 countries in the period of 2008-2017. In the study, dynamic spatial models for pooled time series and cross-sectional data and dynamic spatial panel data models were used.
\end{abstract}

Keywords: government bonds, bond rating, bond yield, dynamic spatial models for pooled time series and cross-sectional data, dynamic spatial panel data models

JEL: G12, G17, E43, H63 


\section{Introduction}

One of the basic risk categories associated with investing in government bonds involves the credit risk defined as the probability of a country's default in meeting the terms and conditions of an agreement. This happens when governments are unable to fulfil their obligations and therefore cease to repay them or, at best, restructure them. An observable regularity is that the yield on bonds increases along with an increasing risk of a country's default (Jajuga, 2009: 23).

A rapid increase in yield spreads was noted during the period of an outbreak of the subprime crisis of 2008-2009 and its expansion onto international financial markets. The growing imbalance in the current accounts of particular countries, especially in the euro area, was quickly reflected in an increase in the yields of government bonds issued by them. The regularities observed in yield spreads at that time did not find an adequate or exhaustive justification in the level of real economic growth, the inflation rate or the development of the fiscal situation of indebted countries, that is, the factors which are considered to be among the basic determinants of government bond yields.

Formal measurement of the risk associated with a country's default is performed by credit rating agencies. The classifications of bond investment quality published by the agencies are based on credit risk models. They take into account a different kind of statistical information concerning the macroeconomic fundaments of a given economy, market prices of debt instruments, and also the qualitative factors related, for example, to the stability and maturity of the political system. Some of the most important economic indicators taken into account by credit rating agencies' analysts in assessing a country's risk is the debt ratio understood as the ratio of the public debt to the value of gross domestic product or, optionally, the national income.

The transparent structure of the cause-and-effect dependence noted by credit rating agencies is supported by underlying theories which logically justify the occurring regularities. On this basis, credit rating agencies decide to change the creditworthiness rating of bonds issued by particular countries, which, in consequence, means that particularly unfavourable changes in credit ratings may have an influence on the yield of debt instruments. What is particularly important, however, is that these changes may concern not only the yield of instruments issued by the country concerned in the assessment but also other spatially related economies.

The issue regarding the impact of changes in the credit rating assessment of debt instruments on their yield is a problem widely discussed in the literature (e.g.: Hand, Holthausen, Leftwich, 1992; Cantor, Packer, 1994; Larrain, Reisen, von Maltzan, 1997; Reisen, von Maltzan, 1998; Steiner, Heinke, 2001; Kaminsky, Schmukler, 2002; Almeida, Cunha, Ferreira, Restrepo, 2014; El-Shagi, von Schweinitz, 2016). In many debates, especially with political and public narratives, an answer is being sought as to whether a negative change in the credit rat- 
ing of the government bonds being issued may result in an increase in their yield. In a frequently cited study by Stiglitz, Ferri and Liu (1999), the authors suggest that such a scenario is likely.

An analysis of spatial dependence which may lead to a spillover effect is a less recognised direction of empirical studies. As a consequence of this phenomenon, the impulses that occur within a single economy may be transmitted to others via various channels.

Scanty analyses performed in this context and devoted to the impact of changes in the ratings of a given country's bonds on the other countries' government bonds provide evidence that this phenomenon indeed exists.

According to Stiglitz, Ferii and Liu (1999), credit rating assessments published by credit rating agencies contributed to the expansion of the Asian crisis in the 1990s. Their arguments are based on the bankruptcy of Thailand in October 1997, whose rating was reduced from A- to BBB, next on Malaysia, which declared bankruptcy in December of the same year and whose rating was reduced from $\mathrm{A}+$ to $\mathrm{A}$, and Indonesia (December, $\mathrm{BBB}$ on $\mathrm{BB}+$ ).

Similar conclusions arise in connection with the empirical analyses of the $\mathrm{Eu}-$ ropean debt crisis conducted by Arezki, Candelon and Sy (2011). The authors state that the macroeconomic downgrading of European peripheral countries' ratings were not justified by macroeconomic fundamentals and resulted in a pressure which further led to an increase in the profitability of their government bonds, thus resulting in an outbreak of the European debt crisis. Of particular interest, however, is the fact that, as the authors emphasise, the downgrading of Greece's rating from A- to BBB+ by Fitch on 8 December, 2009 caused the so-called effect of contagion. Based on the methodology of event analysis, Arezki, Candelon and Sy (2011) confirmed the hypothesis of this phenomenon being caused by a negative change in the credit rating of the source country, thus leading to a change in the profitability of the CDSs issued by other countries interconnected via financial channels. Analyses carried out by Beirne and Fratzscher (2013) seem to confirm earlier findings of the authors quoted above.

Also, the results of independent empirical analyses carried out by Afonso, Furceri and Gomes (2011) regarding the impact of announcements published by credit rating agencies on government bonds yield spreads issued by twenty-four countries from the European Union indicate a significant relationship between the changes in credit quality assessments of debt instruments and the level of bond yields issued by other economies. Thus, the conclusion concerning the existence of certain spatial channels of dependence through which some markets are able to interact in different ways and with varying strength with other markets was confirmed (see also Reinhart, Rogoff, Savastano, 2003). However, as the authors emphasise, unfavourable changes in ratings have an even stronger impact on the government bonds yield issued by related economies than an increase in the credit rating of a given country. 
The asymmetry of the contagion effect with regard to changes in the credit rating of the government bond yield was also confirmed by Gande and Parsley (2003). In the analysis of thirty-four developed and developing economies concerning the period from 1991 to 2000 , the authors proved that positive changes in the ratings of related countries had a negligible impact on the yield spread of government bonds issued by a given country, while their downgrading resulted in a significant increase. Among the channels through which the transmission takes place, the authors considered the value of bilateral capital and trade flows, cultural and institutional links, as well as the physical distance between particular countries. As was demonstrated, along with an increase in the trade exchange between countries, the downgrading of the credit rating of one of them resulted in a stronger reaction of the other country in the form of an increase in the yield of bonds issued by that country.

The considerations of this paper are focused on the analysis of interactions between the yields of 10-year government bonds issued by selected economies. A subject that is of particular interest is the evaluation of the impact of positive and negative changes in credit rating assessments made by international agencies on yield of bonds issued by other economies than the country concerned in the assessment. Therefore, the question of the presence of spatial interactions between the analysed instruments has been considered. The main motivation for joining the discussion on this subject is the insufficient exploration of the analysed problem in the existing literature. The study will subject to verification the hypothesis according to which the changes in ratings not only affect the yields of the bonds of the countries they concern, but also those issued by "neighbouring" economies with regard to a selected criterion, though this relationship is asymmetrical.

\section{The subject and scope of the study}

The paper concerns the impact of announcements made by credit rating agencies on the yield of ten-year government bonds issued by 40 economies from different regions of the world in the period between 2008 and 2017. Selection of the countries was motivated by their importance for the global economy and data availability. The list of countries covered by the study is presented in Table 1. The subject of particular interest consists in the issue related to spatial dependencies that are indicated in the literature, yet are insufficiently explored, as a result of which changes in the creditworthiness of government bonds issued by a specific country lead to changes in the yield of bonds issued by other economies.

In the modelling of spatial dependence, the yield to maturity (YTM) was used as the dependent variable, that is, the so-called internal rate of return, whose theoretical construction allows us to compare bonds of the same type. An additional justification for applying such a measure of the yield of T-bonds lies in the fact that it takes into ac- 
count the changes in time of value of money. Among the explanatory variables which were included in the models used in our investigation (see Section 4), there are: the inflation rate (an increase in inflation reduces the competitiveness of the national economy), the level of integration of government bond markets measured by $\beta$ convergence (an increase in the level of integration causes the distribution of the government bond yield across all countries to be dependent on the strength of the mutual integration of the bond market), the VIX index reflecting the anxiety in the global financial market (Volatility Index - the high value of this index informs about the growing anxiety in the global financial market), and two binary variables respectively regarding positive and negative changes in the rating of bonds issued by the $i$-th country taking the following forms:

$$
\text { Rating_decrease }_{i t}=\left\{\begin{array}{l}
1, \text { downgrading compared to previous year, } \\
0, \text { maintaining rating or raising it, }
\end{array}\right.
$$

Rating_increase ${ }_{i t}=\left\{\begin{array}{l}1, \text { raising the rating in relation to the previous year, } \\ 0, \text { maintaining rating or downgrading. }\end{array}\right.$

Table 1. Spatial scope of the analysis

\begin{tabular}{|c|c|c|c|c|}
\hline \multicolumn{5}{|c|}{ Country } \\
\hline Australia & Austria & Belgium & Canada & Chile \\
\hline China & Colombia & Croatia & Czech Rep. & Denmark \\
\hline Finland & France & Germany & Great Britain & Greece \\
\hline Hungary & India & Indonesia & Ireland & Italy \\
\hline Japan & South Korea & Malaysia & Netherlands & New Zealand \\
\hline Norway & Pakistan & Peru & Philippines & Poland \\
\hline Portugal & Russia & Singapore & Spain & Sweden \\
\hline Switzerland & Taiwan & Thailand & USA & Venezuela \\
\hline
\end{tabular}

Source: the authors' own elaboration

The annual frequency data from the Bloomberg website (https://www.bloomberg.com) were used. The graphs and charts included in the paper were prepared using the MapViewer and OriginPro2018 programs.

\section{Preliminary analysis of selected data}

In Figure 1, the government bond markets covered by the study are marked including an indication of the value of the ratio of public debt to gross domestic product considered as one of the basic factors determining the yield on government bonds. Along with an increase in this ratio, investors can expect a higher risk premium, which leads to an increase in the interest rate on bonds. This, in turn, affects the rate of debt accumulation, thus stimulating a further increase in the ratio's value. 


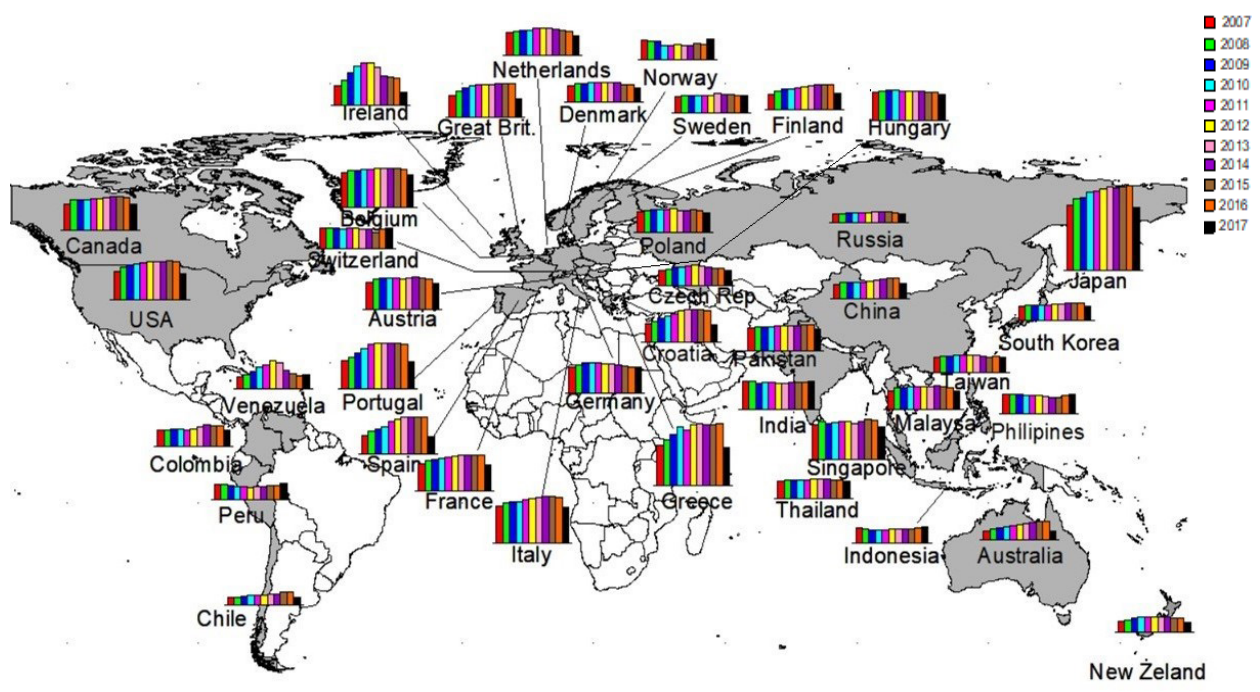

Figure1. Values of the public debt ratio in relation to gross domestic product of the analysed countries in the period of 2007-2017

Source: the authors' own elaboration

The permissible level of indebtedness of 60 percent of the GDP value in the European Union countries does not offer a logical justification for setting the border value for many developed economies that do not belong to the community. A perfect example is Japan, characterised by the value of debt far exceeding the GDP. Nevertheless, in the case of other economies, especially those belonging to the European Union, even the values that did not exceed the borderline level led to a debt crisis in particular in southern European peripheral countries. As can be seen in Figure 1, its culmination took place in the period between the years 2011 and 2014.

The consecutive Figures 2 and 3 show the yield of 10 -year government bonds issued by selected forty countries. In order to ensure proper transparency, it was decided to divide the countries into two groups. Figure 2 presents the profitability of bonds issued by those countries whose bonds in the analysed period were characterised by a lower average interest rate. Figure 3, in turn, reflects the yield on bonds with a significantly higher interest rate (note: the scale on the vertical axis in Figure 3 is different from the scale in Figure 2).

It is worth noting that while in Figure 2 the highest bond yields recorded in the period between 2008 and 2011 in most cases do not exceed six percent, the lowest yield of bonds presented in Figure 3 oscillates around this level. 


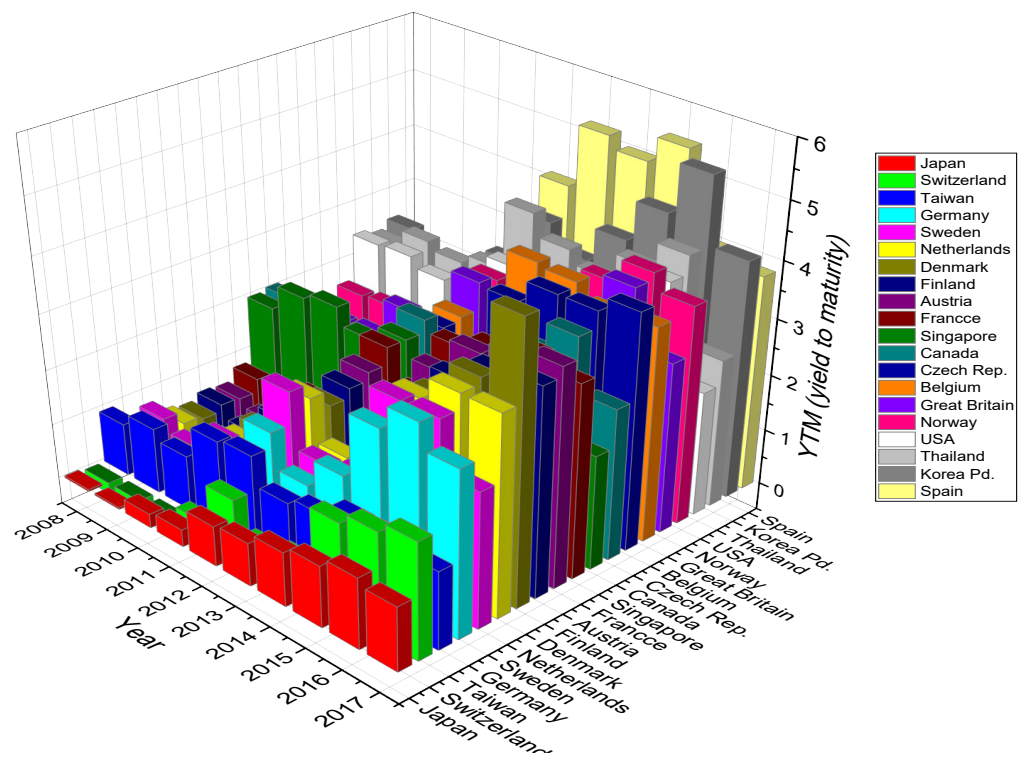

Figure 2. Yield to maturity of 10-year government bonds of selected countries (with a relatively low value of yield) in the period between 2008 and 2017

Source: the authors' own elaboration

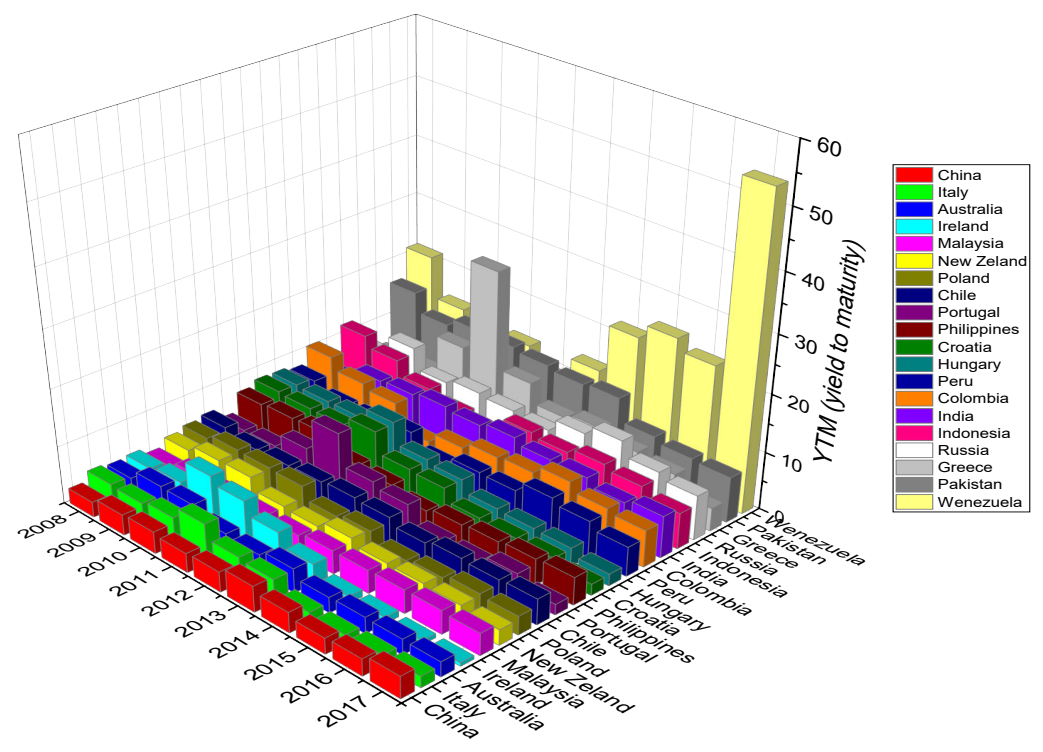

Figure 3. Yield to maturity of 10-year government bonds of selected countries (with a relatively high value of yield) in the period between 2008 and 2017

Source: the authors' own elaboration 
While comparing Figure 1 with the information reflected in Figures 2 and 3, one can identify countries with the so-called debt intolerance. Its essence boils down to the fact that even a relatively small debt ratio in relation to the GDP may indicate problems with external, and ultimately also internal insolvency of a country, which is indirectly reflected in an increase in the yield of government bonds issued by it. As can be seen, this phenomenon concerns such countries as Peru, Indonesia or Russia, whose government bonds, despite the low debt-to-GDP ratio maintained in the period between 2008 and 2017, were characterised by high interest rates in that period.

\section{Methodology}

The empirical analysis of the relationship between the yield of government bonds of selected countries was made using dynamic spatial models for pooled time series and cross-sectional data (TSCS) and dynamic spatial panel data models. Due to the complexity of the phenomenon under consideration, the approach used has several advantages. First of all, the construction of dynamic spatial models TSCS not only enables a thorough understanding of the spatial patterns of the cause-and-effect relationships between the yields of bonds issued by various countries over time but it also allows us to consider the possibility of delayed reactions. In turn, the argument in favour of the construction of empirical dynamic spatial panel data models, besides the previously signalled fact of the existence of spatial and temporal dependencies in the process of shaping the yields of government bonds, was supported by the heterogeneity of the studied economies. Thanks to the individual effects included in the models, the spatial heterogeneity of objects is taken into account, thus the risk of obtaining a biased estimator caused by the failure to include certain variables in the model that are strictly related to a given economy decreases (Elhorst, 2011: 7).

The dynamic spatial models for pooled time series and cross-sectional data, and dynamic spatial panel data models (Anselin, 2001; 2006; Elhorst, 2001; 2003; 2010; 2013; 2018; Anselin, Florax, Rey, 2004; Anselin, Le Gallo, Jayet, 2004; LeSage, Pace, 2009; Suchecki, 2012) used in our analysis of spatial interactions between government bonds yields in the world took the following forms:

1) model SAR_pooled:

$$
\begin{aligned}
Y T M_{i t}= & \beta_{0}+\beta_{1} Y T M_{i, t-1}+\rho \sum_{j \neq \mathrm{i}} \mathrm{w}_{i j, t} Y_{T M_{j t}}+\beta_{2} \text { Inflation }_{i t}+\beta_{3} \text { Integration }_{t}+ \\
& \beta_{4} \text { VIX } X_{t}+\beta_{5} \text { Rating_decrease } \\
i t & +\beta_{6} \text { Rating_increase }_{i t}+\varepsilon_{i t}
\end{aligned}
$$


2) model SEM_pooled:

$$
\begin{aligned}
& Y T M_{i t}=\beta_{0}+\beta_{1} Y_{T M}, t-1+\beta_{2} \text { Inflation }_{i t}+\beta_{3} \text { Integration }_{t}+\beta_{4} V_{\text {VIX }}+ \\
& \beta_{5} \text { Rating_decrease }{ }_{i t}+\beta_{6} \text { Rating_increase }_{i t}+\eta_{i t}, \eta_{i t}=\lambda \sum_{j \neq i} w_{i j, t} \eta_{j t}+\varepsilon_{i t} \text {; }
\end{aligned}
$$

3) model SDM_pooled:

$$
\begin{aligned}
& Y T M_{i t}=\beta_{0}+\beta_{1} Y T M_{i, t-1}+\rho \sum_{i \neq j} w_{i j, t} Y_{T M}+\beta_{2} \text { Inflation }_{i t}+\beta_{3} \text { Integration }_{t}+ \\
& \beta_{4} V I X_{t}+\beta_{5} \text { Rating_decrease }_{i t}+\beta_{6} \text { Rating_increase }_{i t}+ \\
& \beta_{7} \sum_{i \neq j} w_{i j, t} \text { Rating_decrease }_{j t}+\beta_{8} \sum_{i \neq j} w_{i j, t} \text { Rating_increase }_{j t}+\varepsilon_{i t}
\end{aligned}
$$

4) model SAR_FE:

$$
\begin{aligned}
Y T M_{i t}= & \beta_{i}+\beta_{1} Y T M_{i, t-1}+\rho \sum_{j \neq i} w_{i j, t} Y_{T M}+\beta_{j t} \text { Inflation }_{i t}+\beta_{3} \text { Integration }_{t}+ \\
& \beta_{4} \text { VIX }+\beta_{5} \text { Rating_decrease }_{i t}+\beta_{6} \text { Rating_increase }_{i t}+\varepsilon_{i t}
\end{aligned} ;
$$

5) model SEM_FE:

$$
\begin{gathered}
Y_{T M}=\beta_{i}+\beta_{1} Y T M_{i, t-1}+\beta_{2} \text { Inflation }_{i t}+\beta_{3} \text { Integration }_{t}+\beta_{4} V I X_{t}+ \\
\beta_{5} \text { Rating_decrease }_{i t}+\beta_{6} \text { Rating_increas }_{i t}+\eta_{i t}, \eta_{i t}=\lambda \sum_{j \neq i} w_{i j, t} \eta_{j t}+\varepsilon_{i t}
\end{gathered} ;
$$

6) model SDM_FE:

$$
\begin{gathered}
Y_{i T M_{i t}=} \beta_{i}+\beta_{1} Y T M_{i, t-1}+\rho \sum_{j \neq i} w_{i j, t} Y_{T M}+\beta_{2} \text { Inflation }_{i t}+\beta_{3} \text { Integration }_{t}+ \\
\beta_{4} \text { VIX }+\beta_{5} \text { Rating_decrease }_{i t}+\beta_{6} \text { Rating_increase }_{i t}+ \\
\beta_{7} \sum_{i \neq j} w_{i j, t} \text { Rating_decrease }_{j t}+\beta_{8} \sum_{j \neq i} w_{i j, t} \text { Rating_increase }_{j t}+\varepsilon_{i t}
\end{gathered}
$$

where: $Y T M_{i t}$ denotes the yield to maturity of government bonds in the country $i$ at the time $t ; \sum_{i \neq j} w_{i j, t} Y T M_{j t}$ represents values of the variable in the countries related with $i$ according to the economic distance defined by formula (7), at the same time; the variables: Inflation, Integration, VIX, Rating_decrease, Rating_increase have been defined in Section 2. The assessment of the impact of announcements published by credit rating agencies regarding positive and negative changes in the credit quality of bonds issued by the $j$-th country on the $i$-th country's yield bonds was possible due to the introduction of two additional spatially lagged explanatory variables of the zero-one form, i.e.: $\sum_{i \neq j} w_{i j, t}$ Rating_decrease $_{j t}$ and $\sum_{i \neq j} w_{i j, t}$ Rating_increase $_{j t}$. 
The symbols $w_{i j, t}$ appearing in models (1)-(6) come from a connectivity matrix W quantifying the spatial relations between the yield of bonds issued by countries included in the investigation. The basis for its construction was the economic distance measured by the value of the ratio of public debt to gross domestic product. With decreasing the value of the indicator, the strength of spatial connections between objects increases.

The starting point for determining the elements $w_{i j, t}$ consisted in the determination of the economic distance between pairs of objects (economies/countries) according to the following formula (and other formulas, see e.g.: Claeys, Moreno, Suriñach, 2012; Asgharian, Hess, Liu, 2013; Asgharian, Larsson, Liu, 2014; Muratori, 2015):

$$
d_{i j, t}=\left|\frac{d e b t_{i t}}{G D P_{i t}}-\frac{d e b t_{j t}}{G D P_{j t}}\right|,
$$

where:

$\frac{d e b t_{i t}}{G D P_{i t}}, \frac{d e b t_{j t}}{G D P_{j t}}-$ public debt share in GDP in the country $i$ and $j$ in the period $t$.

Subsequently, the components $d_{i j, t}$ should be inversed, i.e.:

$$
d_{i j, t}^{*}=\frac{1}{d_{i j, t}} .
$$

The connectivity matrix must be row standardised, which means that the sum of every row should be equal to 1 . It can be obtained by the following transformation:

$$
w_{i j, t}=\frac{d_{i j, t}^{*}}{\sum_{j} d_{i j, t}^{*}}, \text { for } i=1,2, \ldots, N
$$

Then, the following assumption is true:

$$
\mathbf{W}=\left[w_{i j, t}\right]_{N T \times N T} \forall i \sum_{j=1}^{N T} w_{i j, t}=1 .
$$

The last step involved the construction of a block matrix of cross-sectional and temporal connections between the yield of government bonds of various countries, i.e.: 


$$
\mathbf{W}=\left[\begin{array}{cccc}
\mathbf{W}_{1} & 0 & \ldots & 0 \\
0 & \mathbf{W}_{2} & \ldots & 0 \\
\vdots & \vdots & \ddots & \vdots \\
0 & 0 & \ldots & \mathbf{W}_{10}
\end{array}\right]
$$

where: $\mathbf{W}_{\mathbf{1}} \neq \mathbf{W}_{\mathbf{2}} \neq \ldots \neq \mathbf{W}_{\mathbf{1 0}}$ matrices of spatial connections, taking into account the economic distance between countries, different for the successive years.

The parameter $\rho$ in the models reflects the spatial interactions between the yield of bonds issued by various economies. More precisely, it informs about the reaction force of the $i$-th market to any shock caused by a sudden change in the yield of other countries' bonds related to it through the structure of spatial dependence. In turn, the parameter $\lambda$ informs about the reaction force of $i$-th market to any shock caused by a sudden change in any additional variables not included in the model associated with other countries related to it through the structure of spatial dependence.

The $\beta$ parameters standing next to the spatially non-lagged and non-delayed additional regressors, i.e. parameters $\beta_{1}-\beta_{6}$, should be interpreted as the average immediate impact of changes in additional explanatory variables of the $i$-th country on the yield of bonds issued by it (Kelejian, Tavlas, Hondroyiannis, 2006). The immediate nature of the interaction results from the fact that they are not additionally stimulated by feedback caused by the mutual market reactions to the occurring shocks due to the existence of spatial dependency channels between them.

Then, the parameters $\beta_{7}$ and $\beta_{8}$ appearing in models (3) and (6) demonstrate the influence of changes in the additional explanatory variables relevant for countries spatially related to the $i$-th economy on the yield of bonds issued by it.

\section{Results of the empirical analysis with the use of econometric models}

The empirical analysis of the occurrence of spatial dependence in the shaping of yields on government bonds issued by selected forty countries in relation to the changes in ratings of bonds issued by spatially related economies were carried out using dynamic spatial models for pooled time-series and cross-sectional data and the relevant models for panel data with some elements of space-time dynamics, especially dynamic spatial Durbin models. The results of the estimation and verification of these models are presented in Tables 2 and 3 respectively.

In order to assess the validity of taking into account spatial dependence structures in an analysis of the considered financial processes and phenomena, the research procedure was initiated by constructing an empirical linear model whose 
parameters were estimated using the ordinary least squares method (OLS). The results of the estimation and verification of this model for pooled time series and cross-sectional data (LM_pooled model) show that this model does not meet the basic statistical verification criteria, which is indicated by autocorrelation of the residuals confirmed by the Moran test results. In relation to this model, which can be described as a classical model, the Lagrange Multiplier (LM) tests were also used. The usual LM tests $\left(\mathrm{LM}_{\text {lag }}, \mathrm{LM}_{\text {err }}\right)$ were additionally enhanced with the so-called robust versions $\left(\mathrm{RLM}_{\text {lag }}\right.$ and RLM $\left.\mathrm{Rrr}_{\mathrm{r}}\right)$. Due to this fact, it was possible to take the decision on building an alternative model versions with spatial patterns of relationships. Since RLM err was more significant than RLM $_{\text {lag }}$, it spoke in favour of the creation of a spatial error model. Its construction assumes that the sources of spatial dependence are the variables omitted in the model, therefore, the detection of autocorrelation occurs in a random component.

An amplification of the non-spatial approach was made by introducing into the model the spatial relationships defined by the matrix of economic distances $\mathbf{W}$. As a result, spatial models of autoregressive dependence with spatially lagged variable WYTM (SAR model) and variables WRating_decrease and WRating_increase (SDM model) were obtained.

In the estimated model of spatial autoregression (SAR) and spatial Durbin model (SDM), the statistically significant explanatory variables are those that reflect the level of integration of the global government bond market as well as both binary variables informing of a statistically significant impact of the increase and decrease in the sovereign rating on their yield, which is in accordance with the fact that the sovereign rating is typically listed as one of the yield determinants.

What is particularly interesting in our analysis is that both the parameter $\rho$ and parameter $\beta_{7}$ related to the spatially lagged variables, i.e. WYTM and also weighed by the relevant elements of the matrix $\mathbf{W}$ binary variable reflecting negative changes in the rating of countries considered neighbouring in terms of the value of public debt ratio to the GDP (WRating_decrease) respectively, are statistically significant. It is worth noting, however, that positive changes in the ratings score (WRating_increase) turned out to be statistically insignificant. Therefore, the hypothesis formulated at the beginning of the study, according to which changes in ratings affect not only the yield of bonds of the countries they concern but also bonds issued by neighbouring economies with regard to the selected criterion, with this relationship being asymmetrical, was confirmed. 
Table 2. Results of the estimation and verification of the dynamic spatial models for pooled time series and cross-sectional data

\begin{tabular}{|c|c|c|c|c|}
\hline Variable & LM_pooled & SAR_pooled & SEM_pooled & SDM_pooled \\
\hline Constant & $\begin{array}{c}2.756 \\
(0.010) \\
\end{array}$ & $\begin{array}{c}2.372 \\
(0.026) \\
\end{array}$ & $\begin{array}{c}2.792 \\
(0.024) \\
\end{array}$ & $\begin{array}{c}3.638 \\
(0.002) \\
\end{array}$ \\
\hline$Y T M_{t-1}$ & $\begin{array}{c}-0.055 \\
(0.311) \\
\end{array}$ & $\begin{array}{c}-0.054 \\
(0.306)\end{array}$ & $\begin{array}{c}-0.053 \\
(0.320) \\
\end{array}$ & $\begin{array}{c}-0.063 \\
(0.231) \\
\end{array}$ \\
\hline Inflation & $\begin{array}{c}-0.006 \\
(0.700) \\
\end{array}$ & $\begin{array}{c}-0.010 \\
(0.519) \\
\end{array}$ & $\begin{array}{c}-0.014 \\
(0.377) \\
\end{array}$ & $\begin{array}{c}-0.000 \\
(0.852) \\
\end{array}$ \\
\hline Integration & $\begin{array}{r}-33.678 \\
(0.011)\end{array}$ & $\begin{array}{r}-28.312 \\
(0.032)\end{array}$ & $\begin{array}{r}-33.616 \\
(0.031)\end{array}$ & $\begin{array}{r}-46.455 \\
(0.001)\end{array}$ \\
\hline VIX & $\begin{array}{c}0.458 \\
(0.515)\end{array}$ & $\begin{array}{c}0.344 \\
(0.620)\end{array}$ & $\begin{array}{c}0.456 \\
(0.583)\end{array}$ & $\begin{array}{c}0.346 \\
(0.618)\end{array}$ \\
\hline Rating_decrease & $\begin{array}{c}2.878 \\
(0.000)\end{array}$ & $\begin{array}{c}2.900 \\
(0.000)\end{array}$ & $\begin{array}{c}2.912 \\
(0.000)\end{array}$ & $\begin{array}{c}3.207 \\
(0.000)\end{array}$ \\
\hline Rating_increase & $\begin{array}{c}2.433 \\
(0.001)\end{array}$ & $\begin{array}{c}2.423 \\
(0.001)\end{array}$ & $\begin{array}{c}2.448 \\
(0.001)\end{array}$ & $\begin{array}{c}2.036 \\
(0.004)\end{array}$ \\
\hline WRating_decrease & - & - & - & $\begin{array}{c}7.416 \\
(0.003) \\
\end{array}$ \\
\hline WRating_increase & - & - & - & $\begin{array}{c}3.010 \\
(0.214) \\
\end{array}$ \\
\hline \multicolumn{5}{|c|}{ Autoregressive/autocorrelation parameter } \\
\hline$\rho$ & - & $\begin{array}{c}0.154 \\
(0.052) \\
\end{array}$ & - & $\begin{array}{c}0.334 \\
(0.012) \\
\end{array}$ \\
\hline$\lambda$ & - & - & $\begin{array}{c}0.174 \\
(0.033)\end{array}$ & - \\
\hline $\begin{array}{l}\text { Goodness of fit } \\
\text { Adjusted } R^{2} \\
\text { AIC }\end{array}$ & $\begin{array}{r}0.064 \\
2317.400\end{array}$ & $\begin{array}{c}- \\
2315.600\end{array}$ & $\begin{array}{c}- \\
2314.800\end{array}$ & $\begin{array}{c}- \\
2307.600\end{array}$ \\
\hline $\begin{array}{l}\text { Heteroskedasticity } \\
\text { Breuch-Pagan test }\end{array}$ & $\begin{array}{c}9.174 \\
(0.164)\end{array}$ & $\begin{array}{c}9.137 \\
(0.166)\end{array}$ & $\begin{array}{l}10.122 \\
(0.082)\end{array}$ & $\begin{array}{c}20.975 \\
(0.007)\end{array}$ \\
\hline $\begin{array}{l}\text { Autocorrelation } \\
\text { of residuals } \\
\text { Moran test }\end{array}$ & $\begin{array}{r}-0.064 \\
(0.011) \\
\end{array}$ & $\begin{array}{r}0.009 \\
(0.341) \\
\end{array}$ & $\begin{array}{r}0.003 \\
(0.421) \\
\end{array}$ & $\begin{array}{c}0.000 \\
(0.4357) \\
\end{array}$ \\
\hline $\begin{array}{l}\begin{array}{l}\text { Spatial } \\
\text { dependence }\end{array} \\
\mathrm{LM}_{\text {lag }} \\
\mathrm{LM}_{\text {err }} \\
\mathrm{RLM}_{\text {lag }} \\
\mathrm{RLM}_{\text {err }}\end{array}$ & $\begin{array}{c}3.688 \\
(0.055) \\
4.324 \\
(0.038) \\
0.523 \\
(0.470) \\
1.159 \\
(0.282) \\
\end{array}$ & & & \\
\hline
\end{tabular}


Table 3 contains the results of the estimation and verification of models for the panel data that were used in the study, i.e. the dynamic panel data model with fixed effects without a spatial component, the dynamic spatial autoregressive panel data model with fixed effects and the dynamic spatial Durbin panel data model with fixed effects. The results of the verification of the presented models allow us to recognise the classical linear model as the worst due to the presence of autocorrelation in residuals confirmed by the Moran test results. In order to propose an adequate form of the spatial panel data model, the Lagrange Multiplier tests were used. Since both the usual $\mathrm{LM}_{\text {err }}$ and its robust version RLM err are statistically significant while their counterparts for the spatial autoregressive panel data model, i.e. $\mathrm{LM}_{\text {lag }}$ and $\mathrm{RLM}_{\mathrm{lag}}$, are not, this suggests the need to look for sources of spatial dependence in factors other than spatially lagged YTM (i.e. WYTM).

Table 3. Results of the estimation and verification of the dynamic spatial panel data models

\begin{tabular}{|c|c|c|c|c|}
\hline Variable & LM_FE_IND & SAR_FE_IND & SEM_FE_IND & SDM_FE_IND \\
\hline Constant & $\begin{array}{c}2.193 \\
(0.040)\end{array}$ & $\begin{array}{c}2.038 \\
(0.044)\end{array}$ & $\begin{array}{c}2.513 \\
(0.019)\end{array}$ & $\begin{array}{c}2.115 \\
(0.037)\end{array}$ \\
\hline$Y T M_{t-1}$ & $\begin{array}{c}-0.013 \\
(0.709) \\
\end{array}$ & $\begin{array}{c}-0.014 \\
(0.673)\end{array}$ & $\begin{array}{c}-0.015 \\
(0.659) \\
\end{array}$ & -0.0530 .321 \\
\hline Inflation & $\begin{array}{c}-0.012 \\
(0.268) \\
\end{array}$ & $\begin{array}{c}-0.013 \\
(0.174)\end{array}$ & $\begin{array}{c}-0.017 \\
(0.072) \\
\end{array}$ & $\begin{array}{c}-0.014 \\
(0.151) \\
\end{array}$ \\
\hline Integration & $\begin{array}{r}-33.693 \\
(0.000)\end{array}$ & $\begin{array}{r}-31.241 \\
(0.000)\end{array}$ & $\begin{array}{r}-33.988 \\
(0.000)\end{array}$ & $\begin{array}{r}-31.594 \\
(0.000)\end{array}$ \\
\hline VIX & $\begin{array}{c}0.557 \\
(0.197)\end{array}$ & $\begin{array}{c}0.504 \\
(0.215)\end{array}$ & $\begin{array}{c}0.445 \\
(0.365)\end{array}$ & $\begin{array}{c}-0.456 \\
(0.264)\end{array}$ \\
\hline Rating_decrease & $\begin{array}{c}0.373 \\
(0.445)\end{array}$ & $\begin{array}{c}0.380 \\
(0.406)\end{array}$ & $\begin{array}{c}0.387 \\
(0.396)\end{array}$ & $\begin{array}{c}0.424 \\
(0.353)\end{array}$ \\
\hline Rating_increase & $\begin{array}{r}-0.280 \\
(0.573) \\
\end{array}$ & $\begin{array}{r}-0.250 \\
(0.591) \\
\end{array}$ & $\begin{array}{c}-0.179 \\
(0.699) \\
\end{array}$ & $\begin{array}{c}-0.228 \\
(0.624) \\
\end{array}$ \\
\hline WRating_decrease & - & - & - & $\begin{array}{c}5.327 \\
(0.000)\end{array}$ \\
\hline WRating_increase & - & - & - & $\begin{array}{c}2.829 \\
(0.097) \\
\end{array}$ \\
\hline \multicolumn{5}{|c|}{ Autoregressive/autocorrelation parameter } \\
\hline$\rho$ & - & $\begin{array}{c}0.069 \\
(0.262) \\
\end{array}$ & - & $\begin{array}{c}0.085 \\
(0.172) \\
\end{array}$ \\
\hline$\lambda$ & - & - & $\begin{array}{c}0.183 \\
(0.032)\end{array}$ & - \\
\hline $\begin{array}{l}\text { Goodness of fit } \\
\text { Adjusted } R^{2} \\
\text { AIC }\end{array}$ & $\begin{array}{r}0.650 \\
1961.300\end{array}$ & $\begin{array}{c}- \\
1962.100\end{array}$ & $\begin{array}{c}- \\
1960.300\end{array}$ & $\begin{array}{c}- \\
1953.500\end{array}$ \\
\hline $\begin{array}{l}\text { Heteroskedasticity } \\
\text { Breuch-Pagan test }\end{array}$ & $\begin{array}{l}74.773 \\
(0.003)\end{array}$ & $\begin{array}{l}10.121 \\
(0.133)\end{array}$ & $\begin{array}{l}14.388 \\
(0.092)\end{array}$ & $\begin{array}{c}23.771 \\
(0.017)\end{array}$ \\
\hline
\end{tabular}




\begin{tabular}{|l|c|c|c|c|}
\hline & LM_FE_IND & SAR_FE_IND & SEM_FE_IND & SDM_FE_IND \\
\hline $\begin{array}{l}\text { Autocorrelation } \\
\text { of residuals }\end{array}$ & & & & \\
Moran test & 0.066 & -0.041 & -0.002 & 0.000 \\
& $(0.006)$ & $(0.057)$ & $(0.049)$ & $(0.450)$ \\
\hline Spatial & & & & \\
dependence & 1.236 & & & \\
LM $_{\text {lag }}$ & $(0.266)$ & & & \\
LM $_{\text {err }}$ & 4.604 & & & \\
RLM $_{\text {lag }}$ & $(0.032)$ & & & \\
RLM $_{\text {err }}$ & 0.652 & & & \\
& $(0.419)$ & & & \\
\end{tabular}

Source: the author's own calculations

As a result of considering individual effects, changes in the ratings of the country's bonds ceased to have a statistically significant impact on their yield (in contrast to the TSCS models). In turn, in the dynamic spatial Durbin panel data model, a statistically significant impact of changes in the ratings of related countries on the yield on bonds issued by a given economy was identified only in relation to negative changes in the creditworthiness.

\section{Conclusions}

The results of the study provide evidence of the existence of certain spatial dependence structures due to the presence of which bond markets affect one another. In particular, it concerns the dependence between the government bond yield.

The analysis shows that changes in ratings affect not only the yields of the bonds of the countries they concern but also those issued by "neighbouring" economies with regard to the selected criterion. Simultaneously, it has been found that this relationship is asymmetrical in a sense that negative changes in the ratings of related countries affect the yield on bonds issued by a given country, whereas the influence of positive changes is statistically insignificant. This means that our research hypothesis has been confirmed. The research should be continued with the consideration of an extended time span for the analysis and, perhaps, including in the models successive additional explanatory variables such as deficit and economic growth. Furthermore, we would like to focus on investigating the impact of announcements published by credit rating agencies on the government bond yield at a time before the financial crisis, on the one hand, and after it, on the other hand. 


\section{References}

Afonso A., Furceri D., Gomes P. (2011), Sovereign Credit Ratings and Financial Markets Linkages. Application to European Data, "Journal of International Money and Finance", vol. 31, no. 3, pp. 606-638.

Almeida H., Cunha I., Ferreira M.A., Restrepo F. (2014), The Real Effects of Credit Ratings: The Sovereign Ceiling Channel, "The Journal of Finance", vol. 72, issue 1, pp. 249-290, https:// doi.org/10.1111/jofi.12434.

Anselin L. (2001), Spatial Econometrics, [in:] B.H. Baltagi (ed.), A Companion to Theoretical Econometrics, Basil Blackweel, Oxford, pp. 310-330.

Anselin L. (2006), Spatial Econometrics, [in:] T. C. Mills, K. Patterson (eds.), Palgrave Handbook of Econometrics. Volume 1: Econometrics Theory, Palgrave Macmillan, Basingstoke, pp. 901-941, https://doi.org/10.1111/j.1435-5957.2010.00279.x.

Anselin L., Florax R.J.G.M., Rey S. (2004), Advances in Spatial Econometrics. Methodology, Tools and Applications, Springer-Verlag, New York.

Anselin L., Le Gallo J., Jayet H. (2004), Spatial Panel Econometrics, [in:] L. Matyas, P. Sevestre (eds.), The Econometrics of Panel Data, $3^{\text {th }}$ ed., Kluwer Academic Publishers, Dordrecht.

Arezki R., Candelon B., Sy A.N.R. (2011), Sovereign Rating News and Financial Markets Spillovers: Evidence from the European Debt Crisis, IMF Working Paper 11(68), pp. 1-27.

Asgharian H., Hess W., Liu L. (2013), A spatial analysis of international stock market linkages, Working Paper, School of Economics and Management.

Asgharian H., Larsson M., Liu L. (2014), Spatial dependence in international bond market, http:// www.efmaefm.org/0EFMAMEETINGS/EFMA\%20ANNUAL\%20MEETINGS/2015-Amsterdam/papers/EFMA2015_0226_fullpaper.pdf [accessed: 19.03.2018].

Beirne J., Fratzcher M. (2013), The Pricing of Sovereign Risk and Contagion during the European Sovereign Debt Crisis, "Journal of International Money and Finance", no. 34, pp. 60-82.

Cantor R., Packer F. (1994), Determinants and Impact of Sovereign Credit Ratings, "Economic Policy Review", vol. 2, no. 2, October, pp. 37-43, http://dx.doi.org/10.2139/ssrn.1028774. https:// academiccommons.columbia.edu/catalog?f $\% 5$ bauthor_facet $\% 5 \mathrm{~d} \% 5 \mathrm{~b} \% 5 \mathrm{~d}=$ Stiglitz, $\% 20 \mathrm{Jo}-$ seph\%20E [accessed: 29.06.2018].

Claeys P., Moreno R., Suriñach J. (2012), Debt, interest rates, and integration of financial markets, "Economic Modelling", no. 29, pp. 48-59.

El-Shagi M., Schweinitz G. von (2016), The joint dynamics of sovereign ratings and government bond yields, Discussion Papers 13, Deutsche Bundesbank.

Elhorst J.P. (2001), Dynamic Models in Space and Time, "Geographical Analysis", vol. 33, pp. 119-140.

Elhorst J.P. (2003), Specification and Estimation of Spatial Panel Data Models, "International Regional Science Review", vol. 26, pp. 244-268.

Elhorst J.P. (2010), Applied Spatial Econometrics: Raising the Bar, "Spatial Economic Analysis Journal", vol. 5, no. 1, pp. 9-28, https://doi.org/10.1080/17421770903541772.

Elhorst J.P. (2011), Spatial Panel Models, https://pdfs.semanticscholar.org/66f7/21f336fc5e40aabedf2979c67d0519c20964.pdf [accessed: 29.06.2018].

Elhorst J.P. (2013), Spatial Econometrics. From Cross-Sectional Data to Spatial Panels, Springer Science \& Business Media, https://doi.org/10.1007/978-3-642-40340-8.

Elhorst J.P. (2018), Spillover in space and time: where spatial econometrics and Global VAR models meet, European Central Bank, Working Paper Series, no. 2134.

Gande A., Parsley D.C. (2003), News Spillovers in the Sovereign Debt Market, "Journal of Financial Economics", vol. 75, no. 3, pp. 691-734. 
Hand J.R.M., Holthausen R.W., Leftwich R.W. (1992), The Effect of Bond Rating Agency Announcements on Bond and Stock Prices, "The Journal of Finance", vol. 47, pp. 733-752, https://doi. org/10.1111/j.1540-6261.1992.tb04407.x.

Jajuga K. (ed.) (2009), Zarządzanie ryzykiem, Wydawnictwo Naukowe PWN, Warszawa.

Kaleijan H.H., Tavlas G.S., Hondroyiannis G. (2006), A Spatial Modelling Approach to Contagion among Emerging Economies, “Open Economics Review”, vol. 17, no. 4, pp. 423-441.

Kaminsky G., Schmukler S.L. (2002), Emerging market instability: Do sovereign ratings affect country risk and stock returns, "The World Bank Economic Review", vol. 16, no. 2, pp. 171-195.

Larrain G., Reisen H., Maltzan J. von (1997), Emerging Market Risk and Sovereign Credit Ratings, Working Paper, no. 124.

LeSage J., Pace K. R. (2009), Introduction to Spatial Econometrics, Champion \& Hall/CRC, Boca Raton, London-New York.

Muratori U. (2015), Contagion in the Euro Area Sovereign Bond Market, "Social Sciences", vol. 4(1), pp. 66-82, https://doi.org/10.3390/socsci4010066.

Reinhart C., Rogoff K., Savastano M. (2003), Debt Intolerance, "Brookings Papers on Economic Activity", issue 1, pp. 1-74.

Reisen H., Maltzan J. von (1998), Sovereign credit ratings, emerging market risk and financial market volatility, "Intereconomics", vol. 33, issue 2, pp. 73-82.

Steiner M., Heinke V. G. (2001), Event Study Concerning International Bond Price Effects of Credit Rating Actions, "International Journal of Finance \& Economics", vol. 6, issue 2, pp. 139-157, https://doi.org/10.1002/ijfe.148.

Stiglitz J.E., Ferri G., Liu L.G. (1999), The Procyclical Role of Rating Agencies: Evidence from the East Asian Crisis, "Economic Notes", Columbia University Academic Commons, vol. 28, pp. 335-355, https://doi.org/10.1111/1468-0300.00016.

Suchecki B. (ed.) (2012), Ekonometria przestrzenna II. Modele zaawansowane (Spatial Econometrics II. Advanced Models), Wydawnictwo C.H. Beck, Warszawa.

\section{Przestrzenno-czasowa analiza wpływu ogłoszeń agencji ratingowych na rentowność obligacji skarbowych na świecie w latach 2008-2017}

Streszczenie: Artykuł dotyczy wpływu ogłoszeń publikowanych przez agencje ratingowe na rentowność obligacji skarbowych wybranych krajów świata. Oceny przyznawane dłużnym papierom wartościowym ze względu na standing finansowy emitenta stanowią ważną determinantę ich rentowności. Wśród czynników wpływających na stopę zwrotu danego instrumentu dłużnego, oprócz czynników idiosynkratycznych, czyli związanych z gospodarką emitenta, oraz globalnych, wymienia się także oceny ratingowe krajów powiązanych. Badania empiryczne przeprowadzone w tym zakresie dowodzą ponadto, że relacja ta ma charakter asymetryczny. Pozwala to przypuszczać, że korzystne informacje dotyczące poprawy ratingów obligacji skarbowych nie znajdują odzwierciedlenia w spadku ich rentowności. Celem artykułu jest analiza interakcji między rentownością dziesięcioletnich obligacji skarbowych emitowanych przez wybrane gospodarki. Przedmiotem szczególnego zainteresowania jest ocena wpływu pozytywnych i negatywnych zmian ratingów, dokonywanych przez międzynarodowe agencje, na rentowność obligacji emitowanych przez inne gospodarki niż kraj, do którego odnosi się ocena. Zakres analizy dotyczy dziesięcioletnich obligacji skarbowych emitowanych przez czterdzieści krajów w latach 2008-2017. W pracy wykorzystano przestrzenne modele dla połączonych danych przekrojowych i szeregów czasowych, w tym dynamiczne przestrzenne modele panelowe. 
Słowa kluczowe: obligacje skarbowe, rating obligacji, rentowność obligacji, modele przestrzenne dla połączonych danych przekrojowo-czasowych, dynamiczne przestrzenne modele panelowe JEL: G12, G17, E43, H63

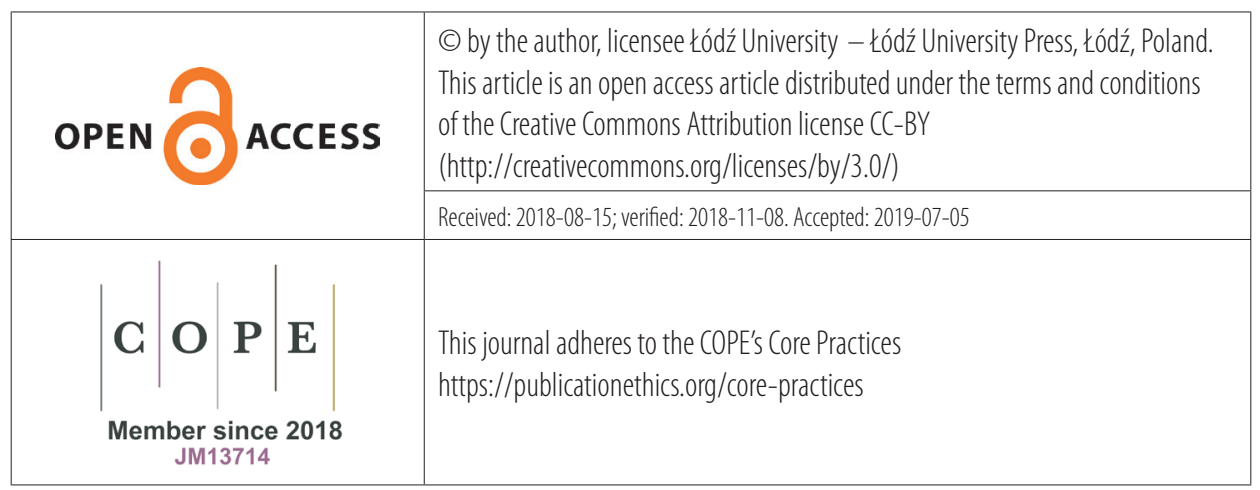

